\title{
Interview with Fernanda Bretones Lane, Guilherme de Paula Costa Santos, Alain El Youssef
}

\author{
Winners of the 2020 Sturgis Leavitt Award for Their Article "The Congress \\ of Vienna and the Making of Second Slavery"
}

The Journal of Global Slavery is delighted to report that the article "The Congress of Vienna and the Making of Second Slavery," authored by Fernanda Pretones Lane, Guilherme de Paula Costa Santos, and Alain ElYoussef, and published in volume 4, issue 2 (2019), was awarded the 2020 Sturgis Leavitt Award for Best Article from the Southeastern Conference on Latin American Studies (SECOLAS). The award is given annually for the best article or book chapter on a Latin American or Iberian subject published by a SECOLAS member in the previous calendar year. We caught up with Fernanda, Guilherme, and Alain, to ask them about their award-winning research, which they illuminated in the following interview.

\section{Congratulations on your prestigious award! Could you please briefly explain} the main findings/arguments of your article for our readers?

Our article focuses on discussions about the abolition of the slave trade held at the Congress of Vienna (1814-1815). We dissect the interests that the Iberian representatives defended in that meeting with regards to the continuation of the slave trade, going against the platform that Britain championed in that occasion. As is well known, the British used the opportunity of having multiple European powers congregated in Vienna to push for the international abolition of the transatlantic traffic of enslaved Africans. This abolitionist agenda was directly opposed to the interests of planters in Cuba and Brazil, who were at the time experiencing an unprecedented growth of commodities production like sugar and coffee, which were produced with enslaved labor. For that reason, Spain and Portugal (the respective empires still controlling those areas) established political and diplomatic strategies to support slavery during the talks held in Vienna-approaches that both would continue to pursue in the following years in the face of unwavering British pressure. Our article shows that the Congress of Vienna was a foundational moment in the formulation of proslavery discourses that supported not only the maintenance of slavery and the slave trade in Cuba and Brazil throughout the nineteenth century, but 
also its expansion. In short, the article positions the Congress of Vienna as integral to the international consolidation of the politics of "second slavery" in the Americas.

\section{How did you come to research this particular theme, and what were your inten- tionsfor doing so?}

In 2013, ADHILAC (Asociación de Historiadores Latinoamericanos y del Caribe) put out a call for papers for a conference celebrating the 2ooth anniversary of the Congress of Vienna with a particular interest in its global dimensions. That was the perfect opportunity for the three of us to collaborate on a paper that could explore one element of the Congress of Vienna that we deemed deserving of attention, namely: the political/diplomatic negotiations that happened in Vienna with regards to slavery and the slave trade. We had each developed separate independent research projects as graduate students at the University of São Paulo (USP) that gave us the necessary background to carry out this collective effort. Guilherme had written a Master's thesis detailing the political and diplomatic debates around the termination of the slave trade that resulted in the 1817 convention between Portugal and Britain, and was in the process of writing a dissertation delving deeper into the Atlantic dimensions of the diplomatic negotiations behind Brazil's independence in the 1820s. Alain studied public debates around slavery and the slave trade in the Brazilian press for his Master's degree, and was working on a dissertation analyzing abolition in the Brazilian empire from a global perspective (it is available at https://www.teses.usp.br/teses/disponiveis/8/8138/tde-30042019 -191619/pt-br.php). Fernanda had recently concluded her Master's thesis, which examined slavery in the Cuban press of the early nineteenth century. Our intention for the conference paper was two-fold. We wanted to try out the hypotheses that Vienna was a formative moment, on an international scale, for formulations of pro-slavery discourses that would shape Spanish and Portuguese (and later Brazilian) politics and diplomacy in the decades to come. And we also wanted to show that collaborative research is possible in the Humanities. Collaborative projects are very common in the "hard" sciences and even among some social scientists, but historians generally privilege single-authored books and articles. Our own training at usp fomented such cooperation, with studentled reading groups and other peer-based initiatives. We thought we achieved these goals with the conference paper, so we decided to keep working on it to publish in a journal. After years of work that included several drafts and many Skype meetings, we were happy that the article found a home in the Journal of Global Slavery. 
How does your research change the way scholars think about the development of Atlantic slavery in the 19th century?

For some time now, scholars have been challenging characterizations of the nineteenth century as "the century of abolition." While it is true that by the end of the 1800 s the institution of slavery would disappear from the legal and political landscape of the Atlantic world, the process was by no means a straightforward progression. On the contrary, Cuba, Brazil and the US South remained as bastions for slavery in the Americas for most of that century, and planters and politicians fought hard not only to defend slavery during that time, but to expand it. Our research sheds light on one particular dimension of the pro-slavery campaign that Iberian actors developed in response to the rising abolitionist movement. We excavated the diplomatic strategies employed by Spanish and Portuguese delegates in Vienna to defend Cuban and Brazilian plantation interests. In doing so, our research positions the Congress of Vienna as a foundational moment for the international consolidation of the politics of "second slavery" in the Americas.

Your work of course centers around the Iberian-American context, but how might your work relate to other studies of slavery across time and space (i.e., what are some of the red threads that slavery scholars should take away from your research)?

There are two threads that we hope our article offers to other slavery scholars. On one hand, our study of the Iberian-American context might inspire similar analysis in other Atlantic and global environments. It would be interesting to see more work on the impacts that the Congress of Vienna and Britain's abolitionist foreign policy had on the slave trade beyond the Iberian-American focus that we offer on the article. On the other hand, the article also offers a methodological model for doing Global History that takes into account the structural relationships between two (or more) spaces.

\section{What will be your next project?}

Alain: Having published my first book based on my Master's thesis (https://www.intermeioscultural.com.br/imprensa-e-escravido--poltica-e -trfi), I am now at work on a second book project that draws on my PhD dissertation. This book will offer an explanation about the end of Brazilian slavery that considers political, economic, and social processes in both the local level and in a global perspective. In it, I develop the concept of "second age of abolition" (1861-1888), pointing specifically to the historical conditions of abolitionism in the US, Cuba, and Brazil vis-a-vis the "first age of abolition" (1777-1863). 
Fernanda: I'm currently working on my first book manuscript, which examines Spain's religious sanctuary policy in the Caribbean (ca. 166os-179os). Religious sanctuary made it possible for enslaved people from foreign colonies to receive asylum and freedom in Spanish territories if they escaped and converted to Catholicism. Wielded as a weapon to destabilize plantation development in rival colonies, the historical life of the policy in the Caribbean illuminates how micro-histories of slave agency and macro-level imperial developments were entwined. I am also putting the finishing touches on an article that examines new meanings of freedom that Africans and people of African descent embraced in the Atlantic world. The article employs the lens of subjectivity in a deep reading of a case involving fugitive slaves from Jamaica who claimed religious sanctuary in Cuba in the mid-eighteenth century.

Guilherme: I am currently at work on a book manuscript based on my $\mathrm{PhD}$ dissertation, which examines the repercussions of diplomatic treatises and proposals (including those relating to the end of the slave trade) on the process of independence and in the formation of the Brazilian Empire. I show the extent to which diplomatic themes and projects were capable of dissuading or fostering internal political resistance that often called into question Emperor D. Pedro I's conduct at the helm of the new empire (1822-1831). Thanks to an award from the Biblioteca Brasiliana Gita e José Mindlin da Universidade de São Paulo (ввм/USP), the book will be launched as part of the commemorations around the bicentennial of Brazilian Independence (1822-2022).

Journal of Global Slavery Editorial Team 